\title{
Does the Repurchase Rate Affect Inflation in South Africa? An Empirical Analysis Using an Impulse Response Function
}

\author{
Temitope L.A. Leshoro \\ University of South Africa (UNISA), South Africa \\ lesholat@unisa.ac.za
}

\begin{abstract}
The repurchase rate (repo rate) is the most common monetary policy instrument that the South African Reserve Bank (SARB) uses to control inflation and endeavours to keep it within the inflation target band of 3\% to 6\%. This study examines the effect of the repo rate on inflation rate along with other variables using the Impulse-Response Function (IRF) of a Vector Autoregressive (VAR) technique. This study uses quarterly data spanning over the period 1980Q2 to 2013Q3. The response of a shock in repo rate on inflation rate and vice versa is generally positive. The results show that given one standard deviation shock in the repo rate, inflation rate will initially increase up until the second quarter after which it starts to decline, and increases again in the fifth quarter. The results obtained from the VAR granger causality test show that repo rate leads the gross domestic product (GDP) growth and inflation rate. There is bidirectional causality between inflation and repo rate; and the result is the same, even after structural break was accounted for. The VAR shows no evidence of instability and autocorrelation, hence the results are reliable. The study suggests some policy recommendations.
\end{abstract}

Keywords: Economic growth, Inflation rate, IRF, Repo rate, VAR

\section{Introduction}

The issue around the effectiveness of the repurchase rate (repo rate) in regulating inflation rate has been a major concern in South Africa. The use of the repo rate was as a result of the adoption of the inflation targeting framework in 2002, even though the South African Reserve Bank (SARB) announced the formal adoption of this framework in February 2000. The SARB has the objectives of price stability and financial stability, its foremost goal is to achieve the latter. The Bank uses many monetary policy instruments to achieve the inflation rate target of $3 \%$ to $6 \%$, but the main instrument used is the repo rate. It is therefore important for an emerging economy such as South Africa to be able to maintain both price stability and attain economic growth. Furthermore, the use of repo rate as the major instrument has not be favourable to some sectors of the economy whereby the main opponent of such approach, Congress of South African Trade Unions (Cosatu), argued that the effect of the inflation targeting through the application of the repo rate has resulted in negative effects on the economic growth. Meanwhile, monetary policy alone cannot lead to sustained economic growth in the long-run; nonetheless it provides an environment where economic growth and development can thrive (South African Reserve Bank, 2014). While the inflation rate in South Africa is relatively low compared to other African countries, except in certain years when it exceeded the set band; it is still imperative to examine the extent to which repo rate helps to regulate the inflation rate and keep it within the target band.

Hence, the focus of this study is to investigate whether inflation rate in South Africa responds to changes in repo rate, thus observing whether the monetary instrument used in achieving the inflation target that the SARB strives for, is indeed plausible or it is detrimental to the economy at large. This study differs from previous studies that examined the effectiveness of repo rate on real economic variables in that this study used the repo rate, rather than using other variables to proxy it and also specifically examining the effect of repo rate on inflation rate and output growth only. The rest of the paper is organized as follows: brief literature on the subject matter is discussed in the next section. Data and methodology are outlined in section 3, while section 4 provides interpretations of the results obtained. Section 5 concludes and suggests possible policy recommendations.

\section{Literature Review}

Many studies have examined the effectiveness of the repo rate on economic variables such as inflation, output growth, house prices to mention a few, for different countries, using different variables and 
various techniques (Gupta, Miller \& van Wyk, 2010; Bonga-bonga \& Kabundi, 2009; Christiano \& Eichenbaum, 1992). This section will review some of these studies. Bonga-bonga \& Kabundi (2009) carried out a study to assess the extent to which the monetary policy tool affect inflation rate in South Africa. They adopted the vector error correction (VEC) model using monthly data over the period 2000:02 to 2007:09. Some of the variables they included are credit extension, log of price levels instead of inflation, production of the manufacturing sector as a proxy for the real gross domestic product (GDP) and JIBAR as a proxy for the monetary policy instrument. Their result supports previous researchers studies that repo rate does not effectively affect inflation rate because the effect of a positive shock in the repo rate rather caused inflation to increase for a period of about 18 months. However, the result obtained by Bonga-bonga \& Kabundi is contrary to the findings of Kabundi \& Ngwenya (2011) when the latter study re-examined the effectiveness of monetary policy on real economic variables in South Africa. Kabundi \& Ngwenya adopted a different technique of Factor-Augmented Vector Autoregressive (FAVAR) framework using monthly data from1985:02 to 2007:11. Some of the variables considered are exchange rate, inflation rate, real economic output, credit and financial market variables and indexes to capture business and consumer confidence. Their result solved the price puzzle by finding inflation to rather decrease with the application of a contractionary monetary policy, even though this decrease only becomes significant around 24 months. This shows that monetary policy is effective in affecting macroeconomic variables.

Furthermore, in a bi-variate study by Gupta \& Komen (2008), they used monthly data spanning over the period 2000:3 to 2007:10. Their study was to find the relationship between monetary policy instrument and nominal target, using repo rate and inflation. They used the conventional Granger causality test as well as its extended version in an error correction mechanism (ECM) and they found that the relationship between these 2 variables is bi-directional. Another study that found the absence of price puzzle was by Gupta et al. (2010), when they assessed the effectiveness of the federal rates on the US house price indexes, using the impulse response functions of the large-scale Bayesian Vector Autoregressive model. Bernake, Boivin \& Eliasz (2003) also used FAVAR technique, but compared it with the VAR technique while measuring the effect of monetary policy on the economy. They found that the 2 methods generally produced similar results, whereby a small but non-trivial effect of monetary policy was found with the possibility of the issue of price puzzle in certain instances. Dickinson \& Riu (2007) also found the effect of monetary policy on the real economy in China using an empirical VAR model. They found that the impact of the monetary policy tool of interest rate on real economy is higher and more significant than the bank lending tool. Many other studies that examined the effect of monetary policy tool on real economy using VAR are Sims (1992), Christiano \& Eichenbaum (1992), Christiano, Eichenbaum \& Evans (1996), Edelberg \& Marshall (1996) and Khan, Kandel \& Sarig (2002).

\section{Data and Methodology}

Quarterly data from 1980Q2 to 2013Q3, with 134 observations was used to analyse whether inflation rate responds to changes in the repo rate. The variables were sourced from the database of the International Monetary Fund and the International Financial Statistics (IMF/IFS). The variables considered are the growth rate of real gross domestic product (GDP), real effective exchange rate (REER) and inflation rate, all at constant 2005 prices, and the repo rate. This study rather uses the repo rate and not a proxy for repo rate such as treasury bill rate, money market rate or the lending rate because this study adopts quarterly data and the South African Reserve Bank (SARB) monetary policy committee (MPC) meets every 2 months, hence the data on repo rate is equally continuous and not discreet. Even though there might not be changes in the repo rate each time the MPC meets, we decided to use the exact repo rate rather than a proxy. A dummy variable was also included to capture the structural break for the adoption of the inflation targeting framework.

The vector autoregressive (VAR) technique by Sims (1980) will be used to analyse the effect of repo rate on inflation rate in South Africa. Many economic variables are believed to be endogenous whereby some variables determine other variables and they are in turn determined by the same variables that they determine in a system of equations. Hence VAR technique assumes that all the variables are endogenous, while determining the valid correlation and dynamic nature of the variables. The impulse-response function (IRF) of estimated vector autoregressive (VAR) model is suitable for policy analysis, where we observe how one variable responds to a one standard deviation shock of another variable. The VAR model written in a compact vector notation form is as follows: 


$$
\bar{W}_{t}=\bar{\Pi}+\phi \bar{X}_{t-1}+\bar{\varepsilon}_{t}
$$

Where $\bar{W}_{t}$ is the vector of dependent variables; $\bar{\Pi}$ is the vector of intercepts; $\phi$ is the vector of coefficients and $\bar{X}_{t-1}$ is the vector of lagged variables and $\bar{\varepsilon}_{t}$ is the vector of error terms.

The multivariate linear simultaneous VAR can also be shown as:

$$
\begin{aligned}
& G D P_{t}=\beta_{0}+\sum_{i=1}^{n} \beta_{1} \text { REER }_{t-i}+\sum_{i=1}^{n} \beta_{2} I N F_{t-i}+\sum_{i=1}^{n} \beta_{3} \text { REPO }_{t-i}+\sum_{i=1}^{n} \beta_{4} G D P_{t-i}+D_{-} I T+\varepsilon_{t} \cdots\{2\} \\
& \text { REER }_{t}=\alpha_{0}+\sum_{i=1}^{n} \alpha_{1} \text { REER }_{t-i}+\sum_{i=1}^{n} \alpha_{2} I N F_{t-i}+\sum_{i=1}^{n} \alpha_{3} R E P O_{t-i}+\sum_{i=1}^{n} \alpha_{4} G D P_{t-i}+D_{-} I T+\mu_{t} \cdot\{3\} \\
& I N F_{t}=\varphi_{0}+\sum_{i=1}^{n} \varphi_{1} \text { REER }_{t-i}+\sum_{i=1}^{n} \varphi_{2} I N F_{t-i}+\sum_{i=1}^{n} \varphi_{3} \operatorname{REPO}_{t-i}+\sum_{i=1}^{n} \varphi_{4} G D P_{t-i}+D_{-} I T+\gamma_{t} \cdots\{4\} \\
& \operatorname{REPO}_{t}=\delta_{0}+\sum_{i=1}^{n} \delta_{1} \operatorname{REER}_{t-i}+\sum_{i=1}^{n} \delta_{2} I N F_{t-i}+\sum_{i=1}^{n} \delta_{3} \operatorname{REPO}_{t-i}+\sum_{i=1}^{n} \delta_{4} G D P_{t-i}+D_{-} I T+\psi_{t} \cdots\{5\}
\end{aligned}
$$

Where all the variables are as earlier defined, $\beta, \alpha, \varphi$ and $\delta$ are intercepts and $\varepsilon, \mu, \gamma$ and $\psi$ are the error terms also called impulses or innovations. D_IT represents the dummy which captures the period of adoption of inflation targeting (IT) of 2002.

$D_{-} I T= \begin{cases}1 & \text { for } I T \text { period } \\ 0 & \text { otherwise }\end{cases}$

While each of the error terms is assumed to be uncorrelated with each other, they also capture the effects of the unexpected shocks of each variable. The equations 2 to 5 illustrate the endogeneity of the system, whereby the current value of each of the variables are explained by the lags of the other variables as well its own lagged values; hence none of the variables is exogenous. Although, the VAR technique treats each variable as endogenous, and the method of estimation is a-theoretical, the inclusion and ordering of variables are based on theory. Granting, the VAR system does not depend on economic theory, the included variables are theory-based; hence VAR is not totally a-theoretical. All the variables in the VAR should be tested for stationarity in order to avoid spurious results and the variables should all be stationary at levels, that is they should be integrated of order zero, I $(0)$. This is because differencing them to become stationary loses the concept of interdependence of the variables (Sims, 1980).The optimal lag length ranging from 1 to $n$ in equations 2 to 5 , will be selected using the minimum value of the lag length criteria of Akaike Information Criterion (AIC) or Schwarz Information Criteria (SC).

\section{Empirical Results}

All the variables were first tested for stationarity and it was found that they were all integrated of order zero, I(0), that is they were all stationary at levels, hence the use of VAR is appropriate. Although the test of unit root is not a pre-requisite for the impulse-response function (IRF) technique, the test was carried out in order to avoid spurious regression results and hence ascertain that the results obtained are reliable. The result of the unit root test is provided in table 1 below:

Table 1: Unit Root test

\begin{tabular}{lllll}
\hline Variables & ADF & PP & DF-GLS & Decision \\
\hline GDP growth & $-6.361^{* * *}$ & $-6.353^{* * *}$ & $-4.814^{* * *}$ & I(0) - Stationary \\
REER & $-5.858^{* * *}$ & $-6.002^{* * *}$ & $-5.810^{* * *}$ & I(0) - Stationary \\
Inflation & $-7.303^{* * *}$ & $-7.482^{* * *}$ & $-7.157^{* * *}$ & I(0) - Stationary \\
Repo & $-4.217^{* * *}$ & $-3.542^{* *}$ & -1.995 & I(0) - Stationary \\
\hline
\end{tabular}

Critical values: Trend and Intercept:

ADF\& PP:-4.028 (1\%); -3.444 (5\%); -3.147 (10\%); DF-GLS: -3.540 (1\%); -2.997 (5\%); -2.707 (10\%)

Next the lag length was determined using the lag length selection criteria of AIC and SC and the optimal lag length of 3 was chosen by considering the criterion with the lower value (See Appendix, Table A1).Although not the focus of this study, the result obtained from the VAR regression is reported in table 2 below; this is followed by the results of the impulse-response function and the causality. The coefficient of each of the estimated parameters in a VAR cannot be interpreted without imposing some form of restriction, however, the interdependence of each variable as well as their levels of significance can be 
observed. We report the results where the dummy, which accounted for the period of the adoption of inflation targeting framework, was included.

Furthermore, by considering equation 4, which is the focus of this study, the VAR result shows that repo rate significantly determines inflation rate in the first 3 period lags, whereby repo rate has a positive effect on inflation rate only in the first and third period lags. Real effective exchange rate does not seem to have any significant effect on inflation rate in South Africa even though there is a negative effect of a one period lag of real exchange rate, after which it changes to a positive one, on inflation rate; this is not significant. There is a positive and significant relationship between inflation and output growth rate in the first period. However, this relationship changes from positive to negative in the second period, while still significant. The adjusted R-squared is reasonably high, showing that about $52 \%$ of all the included variables determine inflation rate. The diagnostic tests show that the VAR is stable (See Appendix, Figure B1) and thus the result of the IRF below is reliable.

Table 2: VAR Result (1980Q2 to 2013Q3)

\begin{tabular}{|c|c|c|c|c|}
\hline Variables & GRW & REER & REPO & INF \\
\hline GRW(-1) & $\begin{array}{l}0.391264 \\
\text { SE: } \quad(0.09072) \\
\text { t-stat: }[4.31273]\end{array}$ & $\begin{array}{l}2618.066 \\
(34414.9) \\
{[0.07607]}\end{array}$ & $\begin{array}{l}0.501434 \\
(0.13777) \\
{[3.63957]}\end{array}$ & $\begin{array}{l}0.241775 \\
(0.12376) \\
{[1.95356]}\end{array}$ \\
\hline GRW(-2) & $\begin{array}{l}0.082660 \\
(0.10155) \\
{[0.81401]}\end{array}$ & $\begin{array}{r}-101333.5 \\
(38521.0) \\
{[-2.63061]}\end{array}$ & $\begin{array}{r}-0.445415 \\
(0.15421) \\
{[-2.88835]}\end{array}$ & $\begin{array}{r}-0.244355 \\
(0.13853) \\
{[-1.76395]}\end{array}$ \\
\hline GRW(-3) & $\begin{array}{c}-0.184912 \\
(0.09309) \\
{[-1.98644]}\end{array}$ & $\begin{array}{l}83131.74 \\
(35311.8) \\
{[2.35422]}\end{array}$ & $\begin{array}{l}0.459605 \\
0.14136) \\
{[3.25123]}\end{array}$ & $\begin{array}{c}0.000540 \\
(0.12699) \\
{[0.00426]}\end{array}$ \\
\hline $\operatorname{REER}(-1)$ & $\begin{array}{c}-3.05 \mathrm{E}-07 \\
(2.3 \mathrm{E}-07) \\
{[-1.31516]}\end{array}$ & $\begin{array}{l}0.609904 \\
(0.08793) \\
{[6.93638]}\end{array}$ & $\begin{array}{c}-5.87 \mathrm{E}-07 \\
(3.5 \mathrm{E}-07) \\
{[-1.66843]}\end{array}$ & $\begin{array}{c}-3.88 \mathrm{E}-07 \\
(3.2 \mathrm{E}-07) \\
{[-1.22657]}\end{array}$ \\
\hline REER(-2) & $\begin{array}{c}2.55 \mathrm{E}-07 \\
(2.7 \mathrm{E}-07) \\
{[0.94448]}\end{array}$ & $\begin{array}{r}-0.058519 \\
(0.10233) \\
{[-0.57186]}\end{array}$ & $\begin{array}{l}3.44 \mathrm{E}-07 \\
(4.1 \mathrm{E}-07) \\
{[0.83912]}\end{array}$ & $\begin{array}{c}4.51 \mathrm{E}-08 \\
(3.7 \mathrm{E}-07) \\
{[0.12247]}\end{array}$ \\
\hline REER(-3) & $\begin{array}{c}6.88 \mathrm{E}-09 \\
(2.3 \mathrm{E}-07) \\
{[0.02929]}\end{array}$ & $\begin{array}{l}0.168036 \\
(0.08907) \\
{[1.88653]}\end{array}$ & $\begin{array}{c}-3.97 \mathrm{E}-07 \\
(3.6 \mathrm{E}-07) \\
{[-1.11212]}\end{array}$ & $\begin{array}{c}9.57 \mathrm{E}-08 \\
(3.2 \mathrm{E}-07) \\
{[0.29880]}\end{array}$ \\
\hline $\operatorname{REPO}(-1)$ & $\begin{array}{r}-0.039966 \\
(0.05816) \\
{[-0.68713]}\end{array}$ & $\begin{array}{l}20555.45 \\
(22064.0) \\
{[0.93163]}\end{array}$ & $\begin{array}{l}1.281882 \\
(0.08833) \\
{[14.5126]}\end{array}$ & $\begin{array}{c}0.242992 \\
(0.07935) \\
{[3.06246]}\end{array}$ \\
\hline REPO(-2) & $\begin{array}{l}0.031117 \\
(0.09116) \\
{[0.34136]}\end{array}$ & $\begin{array}{r}-36860.73 \\
(34578.9) \\
{[-1.06599]}\end{array}$ & $\begin{array}{r}-0.427599 \\
(0.13843) \\
{[-3.08893]}\end{array}$ & $\begin{array}{r}-0.336692 \\
(0.12435) \\
{[-2.70759]}\end{array}$ \\
\hline REPO(-3) & $\begin{array}{c}-0.060184 \\
(0.05932) \\
{[-1.01460]}\end{array}$ & $\begin{array}{l}24245.07 \\
(22501.5) \\
{[1.07749]}\end{array}$ & $\begin{array}{c}0.039982 \\
(0.09008) \\
{[0.44385]}\end{array}$ & $\begin{array}{c}0.113549 \\
(0.08092) \\
{[1.40325]}\end{array}$ \\
\hline $\operatorname{INF}(-1)$ & $\begin{array}{r}-0.064197 \\
0.06466) \\
{[-0.99288]}\end{array}$ & $\begin{array}{r}-24646.48 \\
(24527.3) \\
{[-1.00486]}\end{array}$ & $\begin{array}{l}0.209057 \\
0.09819] \\
{[2.12911]}\end{array}$ & $\begin{array}{c}0.437368 \\
(0.08820) \\
{[4.95861]}\end{array}$ \\
\hline $\operatorname{INF}(-2)$ & $\begin{array}{c}-0.033556 \\
(0.07038) \\
{[-0.47679]}\end{array}$ & $\begin{array}{c}21538.33 \\
(26697.8) \\
{[0.80675]}\end{array}$ & $\begin{array}{c}-0.282124 \\
(0.10688) \\
{[-2.63965]}\end{array}$ & $\begin{array}{r}-0.009847 \\
(0.09601) \\
{[-0.10256]}\end{array}$ \\
\hline
\end{tabular}




\begin{tabular}{lcrrr} 
INF(-3) & -0.107667 & -40032.67 & 0.090469 & 0.269348 \\
& $(0.06455)$ & $(24486.5)$ & {$[0.09803)$} & {$[0.08806)$} \\
& {$[-1.66795]$} & {$[-1.63489]$} & {$[0.92290]$} & {$[3.05878]$} \\
DUMMY & & & & \\
& -0.404993 & 104316.3 & -0.752781 & -0.131366 \\
& $(0.19186)$ & $(72778.7)$ & {$[0.29135)$} & $(0.26172)$ \\
C & {$[-2.11092]$} & {$[1.43334]$} & {$[-2.58373]$} & {$[-0.50193]$} \\
& & & & \\
& 1.892436 & 95084.95 & 1.477044 & 0.564389 \\
R-squared & {$[0.40787)$} & $(154723)$. & {$[0.61940)$} & $0.55641)$ \\
Adj. R-squared & 0.446993 & {$[0.61455]$} & {$[2.38463]$} & {$[1.01435]$} \\
\hline
\end{tabular}

The result of the impulse response function as depicted in figure 1 below is obtained from the VAR estimates. Given an unexpected shock in output growth, inflation rate will initially increase up to the second quarter and starts to fall afterwards. It will increase again between the fourth and the fifth quarter until it starts to stabilize after the sixth quarter. This shows that if there is any form of shock in the GDP growth in South Africa, amongst all other things, inflation rate will be negatively affected for a long period measured in quarters until it stabilizes. The effect of GDP growth on inflation is generally negative and this is line with theory, whereby a decrease in GDP growth will result in an increase in inflation rate and vice versa. Likewise, the real exchange rate is largely negatively related to inflation rate. In the event of a one standard deviation shock in real effective exchange rate, the rate of inflation will decrease up until the third quarter, after which it will increase. Inflation rate will decrease again up until the sixth quarter and thereafter, it will increase up until the last quarter considered. The link between inflation rate and exchange rate can be quite complex, as it can either be positive or negative. The general negative effect of exchange rate on inflation rate shows that if for instance, there is a depreciation of Rand; inflation will increase for at least a period of ten quarters. In the case of South Africa, the relationship between inflation rate and exchange rate is negative.

On the other hand, repo rate has a generally positive effect on inflation rate; this shows that the inflation target framework adopted by the South African Reserve Bank and hence the monetary policy tool of the repurchase rate is effective. A shock in repo rate initially increases the inflation rate up until the second quarter after which it declines and gradually stabilizes. The IRF shows that it will take about nine quarters for inflation rate to fully become stable. This means that in the event of high inflation and the SARB decides to apply a contractionary monetary policy by increasing the repo rate, it should be aware of the fact that this action will take approximately nine quarters before inflation returns to a stable position. The result obtained from the IRF indicates a slight difference from when the structural break is taken into account. The result without the structural break shows that the effect of a shock in repo rate on inflation takes a longer period before it stabilizes.

The granger causality test as shown in the Appendix (Table A2) affirms the result obtained in the vector autoregressive model and the impulse-response function in that, overall, all the other variables jointly explain inflation. However, by considering the effect of each of the determining variables on inflation, only repo rate highly significantly lead inflation rate. Output growth and exchange rates do not lead inflation rate in South Africa. The result further shows that inflation rate also significantly leads repo rate; this is true because given the inflation targeting framework of the South African Reserve Bank, repo rate is used when there is instability in the prices, that is, the monetary policy committee call for the application of the repo rate in the event of increases in inflation.

Also, according to Gupta \&Komen (2008), a properly applied monetary policy should result in bidirectional causality because a change in the target will normally cause monetary authorities to apply and adjust the policy instrument, which should be able to bring the target back to the desired level. This therefore showed that the monetary policy instrument is properly applied in South Africa. In addition, there is bi-directional causality between output growth and repo rate. While, repo rate leads economic growth in South Africa, it is also led by economic growth. This shows that indeed, the SARB could consider targeting another economic variable such as output growth and not only inflation rate. In the event of a 
low economic growth, the SARB can also apply contractionary monetary policy of increased repo rate, in order to bring the economic growth to a satisfactory level.

Figure 1: Impulse-Response Functions
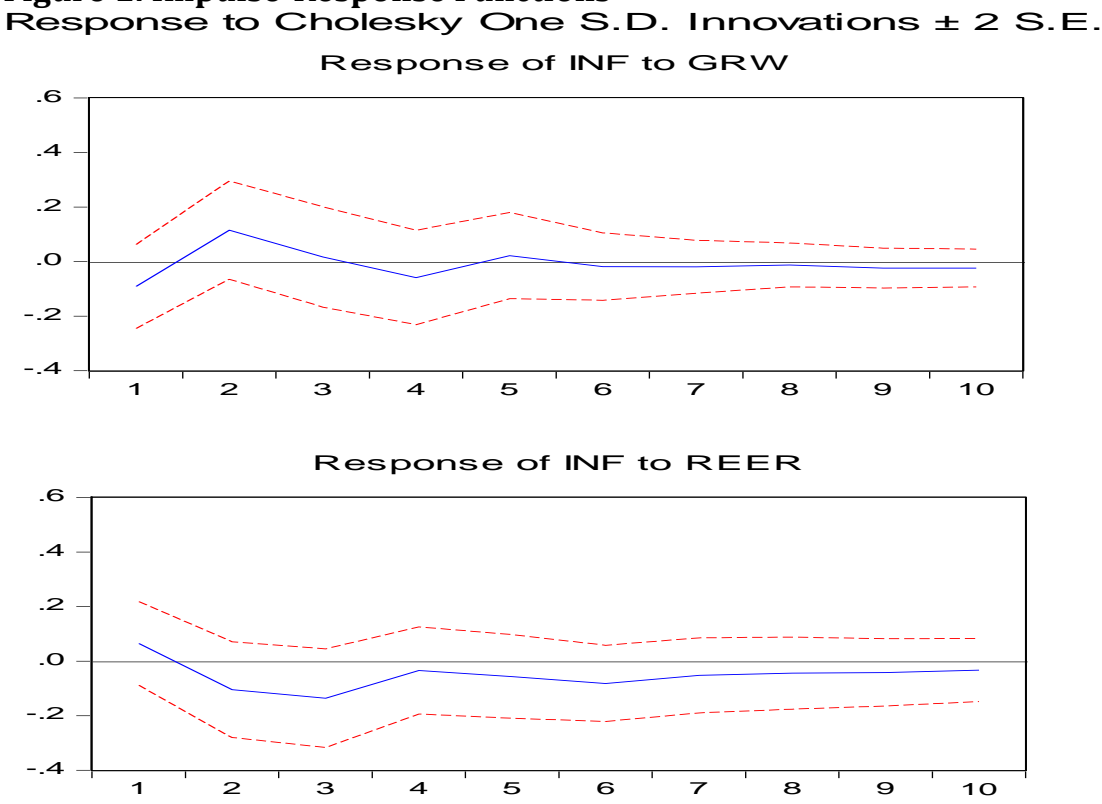

Response of INF to REPO

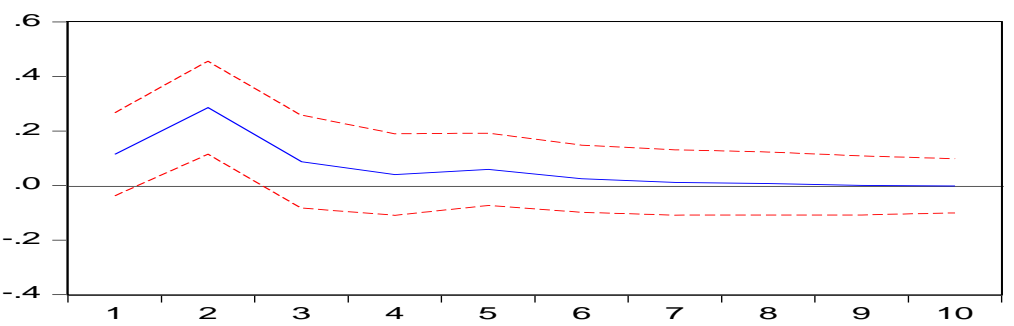

\section{Conclusion and Recommendations}

This study examined whether inflation rate really responds to changes in repo rate in South Africa, using the impulse response function technique of the vector autoregressive analysis. Quarterly data spanning over the period 1980Q2 to 2013Q3 was used. Based on the result obtained from the VAR analysis, the repo rate and output growth significantly explain changes in inflation rate. Further results from the impulse response function show that while the effects of output growth and real exchange rate on inflation rate are generally negative, the effect of repo rate on inflation rate is positive. A shock in repo rate initially increases the inflation rate up until the second quarter after which it declines and stabilizes. It will take about nine quarters for inflation rate to fully become stable after the first application of an increase in repo rate. This means that if the SARB decides to apply a contractionary monetary policy by increasing the repo rate, in the event of high inflation, it should be noted that the effect of this action will take approximately nine quarters before inflation returns to a stable position. Also, there is bi-directional causality between output growth and repo rate. While, the repo rate leads economic growth in South Africa, it is also led by economic growth. This study thus suggests that firstly, the Bank should not apply contractionary monetary policy only in the event of increased inflation rate, but it should equally do so when the economic growth is lower than expected. This means that the Bank should not only target inflation, but consider dual targeting of inflation rate and output growth affirming the suggestion provided by Bonga-bonga \& Kabundi (2009). Secondly, the Bank should not continuously apply contractionary monetary policy when the committee meets every 2 months, in the event of an increase in inflation, but to allow the initial increased repo rate to take effect for some quarters before applying a contractionary policy again if there is need. The reason for this is that based on our results, the application of repo rate takes about nine quarters before its effect can be observed on the level of inflation. 


\section{References}

Bernake, B. S., Boivin, J. \& Eliasz, P. (2003). Measuring the Effects of Monetary Policy: A Factor-Augmented Vector Autoregressive (FAVAR) Approach. 2003 National Bureau of Economic Research, NBER Summer Institute.

Bonga-Bonga, L. \& Kabundi, A. (2009). Monetary Policy Instrument and Inflation in South Africa: Structural Vector Error Correction Model Approach. Paper presented at the $13^{\text {th }}$ Annual Conference of Econometric Modelling for Africa.

Christiano, L. \& Eichenbaum, M. (1992). Identification and the liquidity effect of a monetary policy shock.In: Cukierman, A., Hercowitz, Z., Leiderman, L. (Eds.), Political Economy, Growth, and Business Cycles. MIT Press, Cambridge, MA, 335-370.

Christiano, L., Eichenbaum, M. \& Evans, C. (1996). The effects of monetary policy shocks: evidence from the flow of funds. Review of Economics and Statistics, 78, 16-34.

Dickinson, D. \& Riu, J. (2007). The real effects of monetary policy in China: An empirical analysis. China Economic Review, 18, 87 - 111.

Edelberg, W. \& Marshall, D. (1996).Monetary policy shocks and long-term interest rates. Federal Reserve Bank of Chicago. Economic Perspectives, 20, 2-17.

Gupta, R. \& Komen, K. (2008).Time Aggregation and the Contradictions with Causal Relationships: Can Economic Theory Come to the Rescue? University of Pretoria. Department of Economics Working Paper Series.

Gupta, R., Miller, S. M. \& Van-Wyk, D. (2010). Financial Market Liberalization, Monetary Policy and Housing Price Dynamics. University of Connecticut, Department of Economics Working Paper Series.2010-06.

Kabundi, A. \& Ngwenya, N. (2011). Assessing Monetary Policy in South Africa in A Data-Rich Environment. South African Journal of Economics, 79(1), 91 - 107.

Khan, M., Kandel, S. \& Sarig, K. O. (2002). Real and nominal effects of central bank monetary policy. Journal of Monetary Economics, 49, 1493-1519.

Sims, C. (1992). Interpreting the macro-economic time-series facts: the effects of monetary policy. European Economic Review, 36, 975 - 1000.

Sims, C. (1980). Macroeconomics and Reality. Econometrica, 48, 1 - 49.

South African Reserve Bank (2014). Inflation Targeting Framework.www.resbank.co.za Accessed February $2^{\text {nd }} 2014$.

\section{Appendix}

Table A1: Lag length selection Endogenous variables are: GDP, REPO, INF and REER. Exogenous variable: constant term, C

\begin{tabular}{|c|c|c|c|c|c|c|}
\hline Lag & LogL & LR & FPE & AIC & SC & HQ \\
\hline 0 & -2541.012 & NA & $1.61 \mathrm{e}+12$ & 39.45755 & 39.54623 & 39.49358 \\
\hline 1 & -2274.318 & 512.7133 & $3.30 \mathrm{e}+10$ & 35.57083 & $36.01421^{*}$ & $35.75098^{*}$ \\
\hline 2 & -2255.593 & 34.83870 & $3.16 e+10$ & 35.52857 & 36.32665 & 35.85285 \\
\hline 3 & -2228.310 & 49.06557* & $2.66 \mathrm{e}+10^{*}$ & $35.35365^{*}$ & 36.50644 & 35.82205 \\
\hline 4 & -2223.491 & 8.368401 & $3.18 \mathrm{e}+10$ & 35.52699 & 37.03449 & 36.13952 \\
\hline 5 & -2217.163 & 10.59531 & $3.71 e+10$ & 35.67695 & 37.53915 & 36.43360 \\
\hline \multicolumn{7}{|c|}{ * indicates lag order selected by the criterion } \\
\hline \multicolumn{7}{|c|}{ LR: sequential modified LR test statistic } \\
\hline \multicolumn{7}{|c|}{ FPE: Final prediction error } \\
\hline \multicolumn{7}{|c|}{ AIC: Akaike information criterion } \\
\hline \multicolumn{7}{|c|}{ SC: Schwarz information criterion } \\
\hline \multicolumn{7}{|c|}{ HQ: Hannan-Quinn information criterion } \\
\hline
\end{tabular}


Table A2: VAR Granger Causality Test

\begin{tabular}{lclc}
\hline \multicolumn{2}{l}{ Dependent variable: GRW } & & \\
\hline Excluded & Chi-sq & $\mathrm{df}$ & Prob. \\
REER & 1.875733 & 3 & 0.5986 \\
REPO & 10.98631 & 3 & 0.0118 \\
INF & 8.956229 & 3 & 0.0299 \\
All & 22.90729 & 9 & 0.0064 \\
Dependent variable: REER & & \\
Excluded & Chi-sq & $\mathrm{df}$ & Prob. \\
GRW & 9.302507 & 3 & 0.0255 \\
REPO & 1.872961 & 3 & 0.5992 \\
INF & 4.319102 & 3 & 0.2290 \\
All & 17.31739 & 9 & 0.0440 \\
Dependent variable: REPO & & \\
Excluded & Chi-sq & $\mathrm{df}$ & Prob. \\
GRW & 22.93727 & 3 & 0.0000 \\
REER & 5.109110 & 3 & 0.1640 \\
INF & 8.250089 & 3 & 0.0411 \\
All & 32.19787 & 9 & 0.0002 \\
Dependent variable: INF & & \\
Excluded & Chi-sq & $\mathrm{df}$ & 0.0313 \\
GRW & 5.493954 & 3 & 0.1390 \\
REER & 1.829092 & 3 & 0.0227 \\
REPO & 9.559476 & 3 & \\
All & 18.35019 & 9 & \\
\hline \multicolumn{7}{l}{} & & & \\
\hline
\end{tabular}

Figure B1: VAR Stability Test

Inverse Roots of AR Characteristic Polynomial

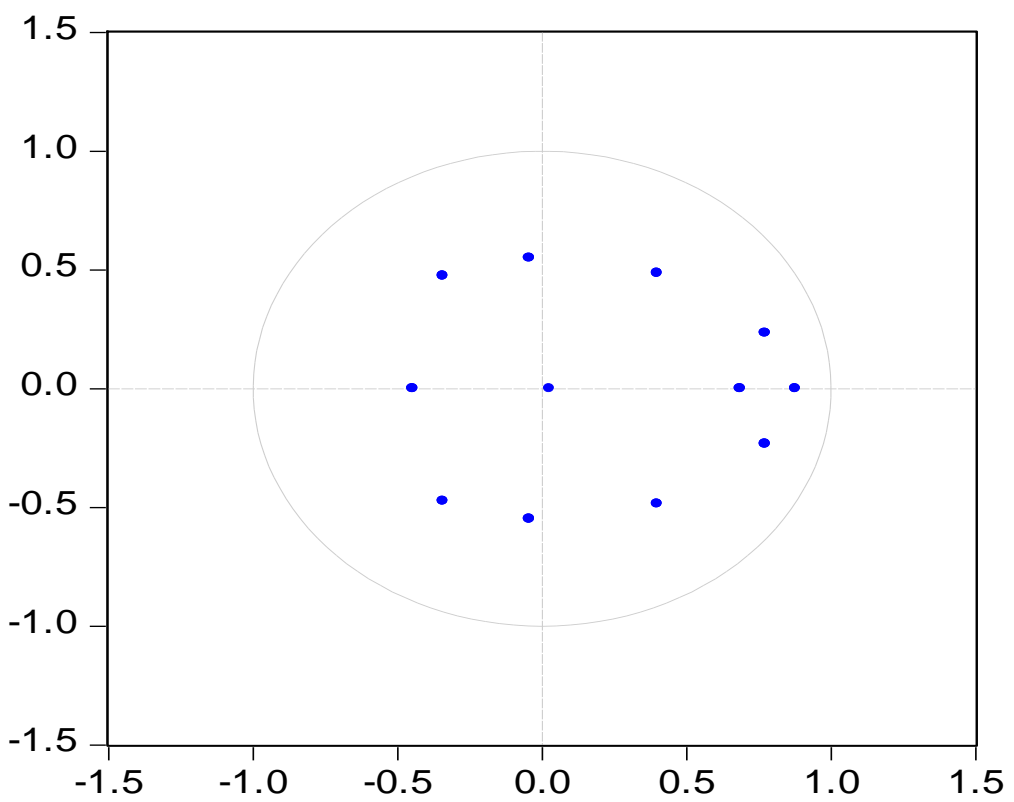

